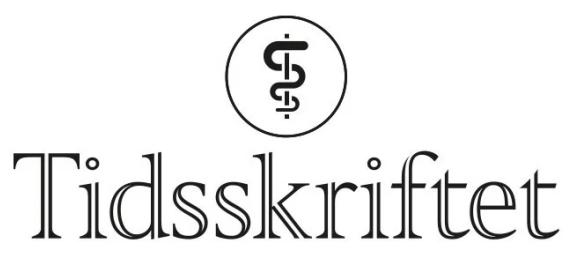

DEN NORSKE LEGEFORENING

\title{
Nyttig om akuttmedisinsk kommunikasjon
}

ANMELDELSER

GUTTORM BRATTEB $\varnothing$

Akuttmedisinsk seksjon Kirurgisk serviceklinikk

Haukeland universitetssykehus

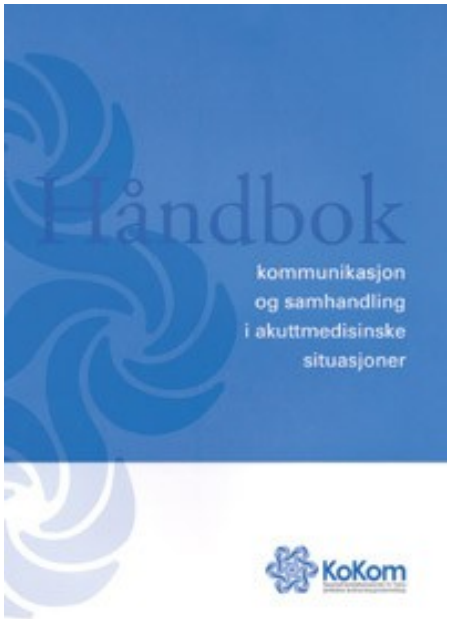

Juvkam, PC

Aksnes, $\mathrm{AO}$

Dreyer, $\mathrm{K}$

Håndbok: Kommunikasjon og samhandling i akutte situasjoner

4. utg. 352 s, tab, ill. Bergen: KoKom, 2009. Pris NOK 150

ISBN 978-82-8210-010-6

«KoKom» lyder den enkle forkortelsen for det mer krevende Nasjonalt kompetansesenter for helsetjenestens kommunikasjonsberedskap. Kompetansesenteret har som hovedoppgave å monitorere og videreutvikle den medisinske nødmeldetjenesten i Norge. Dette er en viktig oppgave, men aller viktigst er det jo at alle aktørene i den 
akuttmedisinske kjeden kjenner systemet og kan utnytte det til beste for pasientene. Her vet vi for eksempel at kommunehelsetjenesten fortsatt har et stykke vei å gå før alle legevaktleger er tilgjengelige over helseradionettet. KoKom har derfor laget en håndbok med beskrivelse av de viktigste regler, forskrifter og lover samt struktur, funksjon og samhandling i vår nasjonale nødmeldetjeneste. Første utgave av denne manualen ble utgitt i 2001, den fjerde er nå tilgjengelig for en billig penge i trykt utgave samt gratis på nett (www.kokom.no).

Boken har en pen layout med fargetrykk og illustrasjoner av høy teknisk kvalitet, ikke minst takket være god papirkvalitet. Det er således klart at utgiveren ikke har som mål å tjene penger, prisen tatt i betraktning. Man får jo kun 7-8 aviser for den beskjedne sum som KoKom krever for håndboken.

Den er forholdsvis enkel å finne frem i, selv om en del av teksten står i så liten skrift at mange av oss over 40 nesten trenger briller eller lupe for å lese den. Teksten er for øvrig grei, men kanskje litt ordrik for en håndbok. Utgivelsen er også generelt omfangsrik og etter min oppfatning kanskje vel omfattende - vedleggene utgjør knapt to tredeler. På den ene side er det jo greit å få en mengde lover, forskrifter og rundskriv samlet, på den annen er jeg redd forfatternes ønske om at dette stoffet skal «bli kjent og lett tilgjengelig» ikke blir oppfylt. Det er kanskje ikke nødvendig å gjengi et rundskriv fra 1992 om krybbedød, pasientskadeloven eller retningslinjer for hjerte-lunge-redning i en håndbok om akuttmedisinsk kommunikasjon. Problemet er jo også at det forholdsvis ofte kommer nye rundskriv og retningslinjer - eksempelvis foreligger det allerede nye for rekvirering av luftambulanse. Kanskje en link til de samme via KoKoms hjemmeside hadde vært en mer hensiktsmessig måte å finne frem til relevante lover ved behov?

Forfatterne er kjente innen det akuttmedisinske miljø og har god kunnskap om den akuttmedisinske hverdag, både i og utenfor sykehus. Selv ville jeg ønske at de hadde kommet med en del historier som kunne illustrert ulike utfordringer innen dette området, basert på personlige og rikholdige erfaringer.

Akuttmedisinske situasjoner krever godt strukturert kommunikasjon uansett hvilken teknisk løsning man benytter, og således vil mye av innholdet være like aktuelt i et fremtidig digitalt kommunikasjonssystem som i dagens analoge verden. Utgivelsen anbefales således for alle AMK- og LV-sentraler samt for kolleger (og andre) med ansvar for legevaktorganisering.

Publisert: 22. oktober 2009. Tidsskr Nor Legeforen. DOI: 10.4045/tidsskr.09.0957

(C) Tidsskrift for Den norske legeforening 2023. Lastet ned fra tidsskriftet.no 26. april 2023. 